\title{
Use of Nitric Oxide Donor Isosorbide Mononitrate for Cervical Ripening at 41 Weeks' Gestation
}

\author{
Mohamed Elmahdy ${ }^{*}$, Hesham Galal ${ }^{1}$, Amany El Marsafawi1, Nahla Amin² \\ ${ }^{1}$ Obstetrics and Gynecology Department, Faculty of Medicine, Alexandria University, Alexandria, Egypt \\ ${ }^{2}$ Ministry of Health Hospitals, Alexandria, Egypt \\ Email: *mahdy_moh@yahoo.com
}

Received 10 June 2016; accepted 2 July 2016; published 5 July 2016

Copyright (C) 2016 by authors and Scientific Research Publishing Inc.

This work is licensed under the Creative Commons Attribution International License (CC BY).

http://creativecommons.org/licenses/by/4.0/

(c) (i) Open Access

\section{Abstract}

Background: The ideal agent for cervical ripening would induce adequate cervical ripening with minimal adverse effects to the mother and the fetus; the most favorable method for cervical ripening is not fully agreed till now; however, vaginal administration of isosorbide mononitrate (IMN) is considered a low-risk method of labor induction for post term. Our study was designed to assess the effect of IMN on cervical ripening and labor induction among 41 weeks pregnant women. Objectives: To assess the efficacy of the nitric oxide donor isosorbide mononitrate on cervical ripening at 41 weeks gestation. Materials and Methods: This study was conducted on 100 pregnant women recruited from the outpatient clinic fulfilling the inclusion criteria. Cases were divided into 2 groups. In first group $40 \mathrm{mg}$ isosorbide mononitrate (IMN) tablet was applied vaginally in posterior fornix, and in second group placebo was applied vaginally in posterior fornix. Following up the cervical status after 24 hours of administration, the patient were asked about new symptoms especially headache, palpitation, dizziness or abdominal pain and the mode of delivery was assessed. Results: There was a significant improvement in the bishop score in the first group rather than the placebo group. No significant difference between the two groups was as regards the mode of delivery. Conclusion: IMN may be used for cervical preparation only before induction of labor in post term cases.

\section{Keywords}

Cervical Ripening, Nitric Oxide Donor, IMN

\footnotetext{
${ }^{*}$ Corresponding author.
}

How to cite this paper: Elmahdy, M., Galal, H., El Marsafawi, A. and Amin, N. (2016) Use of Nitric Oxide Donor Isosorbide Mononitrate for Cervical Ripening at 41 Weeks' Gestation. Open Journal of Obstetrics and Gynecology, 6, 451-456. 


\section{Introduction}

Post term pregnancy refers to any pregnancy that extends after 42 weeks gestation or 294 days past the first day of the last menstrual period [1]. Post term may be in itself high risk. The placenta, which supplies the fetus with nutrients and oxygen from the mother starts aging and will eventually fail [2]. Miscalculation of last menstrual period (LMP) may be common cause of post term [3]. The use of ultrasound in early pregnancy for precise dating significantly reduces the number of post-term pregnancies compared to dating based on the LMP [4].

Post-mature baby is larger than average size baby, so it increases the incidence of cephalopelvic disproportion, shoulder dystocia, operative vaginal delivery [5], postpartum hemorrhage, caesarean sections rate [6] and meconium aspiration [7]. Fetal macrosomia increases incidence of birth injury [8], neonatal encephalopathy [9] and sudden infant death syndrome [10].

Once fetus is diagnosed post-mature, the mother should be offered additional monitoring as this can provide valuable clues that the fetus's health is being maintained. Compared with waiting indefinitely or waiting at least one week for labor to occur spontaneously, labor induction after 41 weeks of gestation is associated with fewer perinatal deaths [11].

Physiological cervical ripening is an active biochemical process; it has been described as an inflammatory process [12]. The Bishop Score is a common measure used to assess the cervical repining [13]. Non-pharmacologic approaches to cervical ripening including herbal compounds, castor oil, hot baths, enemas, sexual intercourse, and breast stimulation till now have not proven efficient for cervical ripening or induction of labor [14]. Surgical methods for cervical repining (stripping of the membranes, amniotomy, balloon catheter insertion in cervix), have been recommended for cervical ripening; however there are risks for this technique including infection, bleeding, accidental rupture of the membranes, and patient discomfort [15] [16].

With pharmacological cervical ripening, Prostaglandins E2 (Misoprostol) are the current method used for cervical ripening and labor induction [17]. But risks associated with its use include uterine hyperstimulation, nausea, vomiting, diarrhea, fever and accompanying FHR changes [18]. Uterine rupture in women with previous cesarean section limits its use to women who have a uterine scar [19]. There is insufficient information to support the use of mifepristone and relaxin for cervical ripening [20]. Oxytocin is the preferred pharmacologic agent for inducing labor when the cervix is favorable or ripe [21].

Nitric oxide (NO) is a small, highly reactive, free radical gas with a half-life time of a few seconds [22], expressed in three isoforms; all of these isoforms are present in various cells of the uterine cervix [23]. Cervical nitric oxide production is very low in post term pregnancy. Thus, it has been suggested that reduced cervical nitric oxide release may contribute to prolonged pregnancy [24]. In cervical ripening, immunological mediators play a crucial role in this process. NO is involved in the acute inflammatory response and amplifies the cytokine cascade stimulated during this response [25], via interactions either with prostaglandin biosynthesis or with lytic enzymes. It stimulates cyclooxygenase to increase the production of pro-inflammatory prostaglandins [26]. Its action is accomplished by effects on connective tissue and smooth muscle cells [27]. Isosorbide mononitrate (IMN) is a drug used principally in the treatment of angina pectoris. Vaginal administration IMN reduces the cervical resistance without inducing uterine hyperstimulation or abnormal fetal heart rate [28].

\section{Patients and Methods}

100 post term pregnant women at 41 weeks gestational age. All patients must fulfill the inclusion criteria; gestational age of 41 weeks, not in labor, cephalic presentation, singleton fetus, having a normal non-stress test and biophysical profile. patients with 3 pregnancy associated diseases as preeclampsia, placenta previa or unexplained vaginal bleeding during pregnancy, cardiac, pulmonary, renal or hepatic disease, history of severe persistent headache, polyhydramnios, placenta previa, probability of placenta abruption or any contraindication for induction of labor were excluded.

This study has been approved by national research ethics committee and has been performed in accordance with the ethical standards as laid down in the 1964 Declaration of Helsinki and its later amendments or comparable ethical standards.

\section{Informed Consent}

"Informed consent was obtained from all individual participants included in the study."

At the first visit each woman will be subjected to: complete history taking, routine investigations: complete 
blood picture, fasting blood sugar and complete urine analysis, general examination, obstetric examination (vaginal examination to assess the pelvis, Bishop score and the presenting part), obstetric ultrasonography, biophysical profile and Doppler to assess fetal wellbeing.

Cases divided into 2 groups, first group received $40 \mathrm{mg}$ IMN tablet applied vaginally in posterior fornix, second group received placebo applied vaginally at the same site. Women were permitted to go home and instructed to come to the hospital immediately if they had any sign of dangerous symptoms (leakage of amniotic fluid, vaginal bleeding or decrease in fetal movements), otherwise they were asked to come back to the hospital after 24. The women were examined vaginally by the same physician to assess the cervical status, fetal monitoring and follow up the case till delivery.

\section{Results}

There was a significant difference between the IMN group and the controls with respect to the Bishop score ( 4.40 vs. $3.68, \mathrm{p}=0.031$ ) (Table 1 ), but there was no significant differences in the mode of delivery between the two groups (Table 2). The major side effect of IMN was headache, about 70\% of cases complain from headache, which responded to a mild analgesia.

\section{Discussion}

Our study demonstrated that outpatient use of IMN has a significant effect in cervical repining and Bishop Score after 24 hours of administration in posterior fornix. In our study 30 women (60\%) in the IMN group in contrast to 10 women (20\%) in the placebo group had positive cervical repining after 24 hours $\left(\mathrm{p}=0.001^{*}\right)$. These results are consistent with previous studies that were done by Erling Ekerhovd in 2003 [28], Maria Bullarbo [29], and Rameez in 2007, which concluded that outpatient cervical ripening followed by labor induction with isosorbide

Table 1. Comparison between the two studied groups regarding the Bishop base score before and after 24 hours of administration.

\begin{tabular}{ccc}
\hline & Study group & Control group \\
\hline Bishop base score before administration & & \\
Min. - Max. & $0.0-6.0$ & $0.0-6.0$ \\
Mean \pm SD. & $3.72 \pm 1.29$ & $3.60 \pm 1.54$ \\
Median & 4.0 & 3.0 \\
p & & 0.471 \\
Bishop score after administration & $0.0-7.0$ & $0.0-7.0$ \\
Min. - Max. & $4.40 \pm 1.81$ & $3.68 \pm 1.73$ \\
Mean \pm SD. & 5.0 & 3.0 \\
Median & & $0.031^{*}$ \\
\hline
\end{tabular}

Table 2. Comparison between the two studied groups regarding the mode of delivery.

\begin{tabular}{ccccc}
\hline & Study group & \multicolumn{2}{c}{ Control group } \\
\hline & No. & $\%$ & No. & $\%$ \\
Mode of delivery & & & 26 & 52.0 \\
Normal vaginal delivery & 32 & 64.0 & 24 & 48.0 \\
C. S. & 18 & 36.0 & & 0.224 \\
p & & & & \\
\hline
\end{tabular}


mononitrate seems to be an effective, safe and well tolerated procedure [30]. Another study done by Eddama et al. demonstrated that the proportion of women with an unripe cervix after $24 \mathrm{~h}$ of outpatient treatment was significantly lower in the IMN group as compared with the placebo group (64\% vs. 77\%, p $=0.02$ ) [31]. In our study there was a significant difference between the IMN group and the controls with respect to the Bishop score $\left(4.40\right.$ vs. $3.68, \mathrm{p}=0.031^{*}$ ), which was consistent with Hamideh Yazdizadeh et al. in which there was a significant difference between the IMN group and the control group with respect to the Bishop score (4.92 vs. 4.03, $\mathrm{p}=0.01$ ) [32]. In another study done by Kavita Agarwal et al., the Bishop score was significantly improved 24 hours after initiation of the outpatient IMN treatment $(p<0.001)$ and the needs for further cervical ripening and oxytocin infusion were less in the study than in the control group $(p<0.001$ and $p=0.008)$ [33].

In this study there were no significant differences in the mode of delivery between the two groups, as 32 women treated with isosorbide mononitrate went into normal labor compared to 26 women in the placebo group ( $p>0.05$ ); there were no significant differences as regard to normal labor. In Mohamed Furukan study it was reported that there was marked increase in the proportion establishing spontaneous labor $(28 \%$ vs. $7.5 \%$, p < 0.01 ) and cervix was favorable for oxytocin infusion (40\% vs. $9 \%, \mathrm{p}<0.001) 2$ days after therapy; in the same study the cesarean section rates were similar in both groups [30].

In our study there were no significant differences in cesarean delivery rate (36\% vs. 48\%, p > 0.05), neonatal outcomes and Apgar score between the two groups, consistent with Sherif M. Habib et al. study [34].

The most common side effect in women treated with IMN was headache, experienced by 35 women (70\%) compared to 4 women $(8 \%)$ in placebo group ( $<<0.05)$; the intensity of headache was from mild to moderate headache. However Maria Bullarbo reported that higher incidence (88\%) of women treated with isosorbide mononitrite was complained from headache compared to (4\%) in placebo group [29].

So, vaginal administration of IMN reduces the cervical resistance and induces cervical ripening without inducing uterine hyperstimulation or abnormal fetal heart rate. So IMN can be used in outpatient clinic for cervical ripening with no need for admission or close fetal monitoring.

\section{Disclosure Statement}

There is nothing to disclose.

\section{References}

[1] ACOG Practice Bulletin (2004) Clinical Management Guidelines for Obstetricians-Gynecologists. Management of Postterm Pregnancy. Obstetrics \& Gynecology, 104, 639-646.

[2] Olesen, A.W., Westergaard, J.G. and Olsen, J. (2003) Prinatal and Maternal Complication Related to Postterm Delivery: National Register-Based Study, 1978-1993. American Journal of Obstetrics \& Gynecology, 189, 222-227. http://dx.doi.org/10.1067/mob.2003.446

[3] Savitz, D.A., Terry Jr, J.W., Dole, N., Thorp Jr, J.M., Siega-Riz, A.M. and Herring, A.H. (2002) Comparison of Pregnancy Dating by Last Menstrual Period, Ultrasound Scanning, and Their Combination. American Journal of Obstetrics \& Gynecology, 187, 1660-1666. http://dx.doi.org/10.1067/mob.2002.127601

[4] Meir, Y., Mandruzzato, G. and D’Ottavio, G. (1999) Management of Post Term Pregnancy. In: Chervenak, K., Ed., The Fetus as a Patient, Parthenon Publishing, New York, 36-37.

[5] Alexander, J.M., McIntire, D.D. and Leveno, K.J. (2000) Forty Weeks and beyond: Pregnancy Outcomes by Week of Gestation. Obstetrics \& Gynecology, 96, 291-294. http://dx.doi.org/10.1097/00006250-200008000-00026

[6] Treger, M., Hallak, M., Silberstein, T., Friger, M., Katz, M. and Mazor, M. (2002) Post-Term Pregnancy: Should Induction of Labor Be Considered before 42 Weeks. Journal of Maternal-Fetal \& Neonatal Medicine, 11, 50-53. http://dx.doi.org/10.1080/jmf.11.1.50.53

[7] Kabbur, P.M., Herson, V.C., Zaremba, S. and Lerer, T. (2005) Have the Year 2000 Neonatal Resuscitation Program Guidelines Changed the Delivery Room Management or Outcome of Meconium-Stained Infants? Journal of Perinatology, 25, 694-697. http://dx.doi.org/10.1038/sj.jp.7211385

[8] Rosen, M.G. and Dickinson, J.C. (1992) Management of Post-Term Pregnancy. New England Journal of Medicine, 326, 1628-1629. http://dx.doi.org/10.1056/NEJM199206113262409

[9] Badawi, N., Kurinczuk, J.J., Keogh, J.M., Alessandri, L.M., O’Sullivan, F., Burton, P.R., et al. (1998) Antepartum Risk Factors for Newborn Encephalopathy: The Western Australian Case-Control Study. BMJ, 317, 1549-1553. http://dx.doi.org/10.1136/bmj.317.7172.1549 
[10] Hilder, L., Costeloe, K. and Thilaganathan, B. (1998) Prolonged Pregnancy: Evaluating Gestation-Specific Risks of Fetal and Infant Mortality. British Journal of Obstetrics and Gynaecology, 105, 169-173. http://dx.doi.org/10.1111/j.1471-0528.1998.tb10047.x

[11] Watson, W.J., Stevens, D., Welter, S. and Day, D. (1996) Factors Predicting Successful Labor Induction. Obstetrics \& Gynecology, 88, 990-992. http://dx.doi.org/10.1016/S0029-7844(96)00321-3

[12] Denison, F.C., Calder, A.A. and Kelly, R.W. (1999) The Action of Prostaglandins E2 on Human Cervix: Stimulation of Interleukin 8 and Inhibition of Secertory Leucocyte Protease Inhibitor. American Journal of Obstetrics \& Gynecology, 180, 614-620. http://dx.doi.org/10.1016/S0002-9378(99)70263-2

[13] Laughon, S.K. (2011) Using a Simplified Bishop Score to Predict Vaginal Delivery. Obstetrics \& Gynecology, 117, 805-811. http://dx.doi.org/10.1097/AOG.0b013e3182114ad2

[14] Adair, C.D. (2000) Nonpharmacologic Approaches to Cervical Priming and Labor Induction. Clinical Obstetrics and Gynecology, 43, 447-454. http://dx.doi.org/10.1097/00003081-200009000-00005

[15] Hadi, H. (2000) Cervical Ripening and Labor Induction: Clinical Guidelines. Clinical Obstetrics and Gynecology, 43, 524-536. http://dx.doi.org/10.1097/00003081-200009000-00012

[16] Vaknin, Z., Kurzweil, Y. and Sherman, D. (2010) Foley Catheter Balloon vs Locally Applied Prostaglandins for Cervical Ripening and Labor Induction: A Systematic Review and Metaanalysis. American Journal of Obstetrics and Gynecology, 203, 418-429. http://dx.doi.org/10.1016/j.ajog.2010.04.038

[17] American College of Obstetricians and Gynecologists (1999) Induction of Labor with Misoprostol. ACOG Committee Opinion 228, ACOG, Washington DC, 2.

[18] Goldman, J.B. and Wigton, T.R. (1999) A Randomized Comparison of Extra-Amniotic Saline Infusion and Intracervical Dinoprostone Gel for Cervical Ripening. Obstetrics \& Gynecology, 93, 271-274. http://dx.doi.org/10.1097/00006250-199902000-00021

[19] Goldberg, A.B., Greenberg, M.B. and Darney, P.D. (2001) Misoprostol and Pregnancy. The New England Journal of Medicine, 344, 38-47. http://dx.doi.org/10.1056/NEJM200101043440107

[20] Neilson, J.P. (2002) Mifepristone for Induction of Labour. Cochrane Database of Systematic Reviews, 2, CD002865.

[21] Arias, F. (2000) Pharmacology of Oxytocin and Prostaglandins. Clinical Obstetrics \& Gynecology, 43, 455-468. http://dx.doi.org/10.1097/00003081-200009000-00006

[22] Aktan, F. (2004) INOS-Mediated Nitric Oxide Production and Its Regulation. Life Sciences, 75, 639-653. http://dx.doi.org/10.1016/j.lfs.2003.10.042

[23] Bao, S., Rai, J. and Schreiber, J. (2001) Brain Nitric Oxide Synthase Expression Is Enhanced in the Human Cervix in Labor. Journal of the Society for Gynecologic Investigation, 8, 158-164. http://dx.doi.org/10.1016/S1071-5576(01)00106-X

[24] Chanrachakul, B., Herabutya, Y. and Punyavachira, P. (2000) Potential Efficacy of Nitric Oxide for Cervical Ripening in Pregnancy at Term. International Journal of Gynecology \& Obstetrics, 71, 217-219. http://dx.doi.org/10.1016/S0020-7292(00)00284-8

[25] Lanaro, A., O’Donnell, C.A., Di Rosa, M. and Liew, F.Y. (1994) A Nitric Oxide Synthase Inhibitor Reduces Inflammation, Down-Regulates Inflammatory Cytokines and Enhances Interleukin-10 Production in Carrageenin-Induced Mice. Immunology, 82, 370-375.

[26] Salvemini, D. and Masferrer, J.L. (1996) Interactions of Nitric Oxide with Cyclooxygenase in Vitro, ex Vivo, and in Vivo Studies. Methods in Enzymology, 269, 15-25. http://dx.doi.org/10.1016/s0076-6879(96)69005-3

[27] Ekerhovd, E., Wejdegård, B., Brännström, M., Mattsby-Baltzer, I. and Norström, A. (2002) Nitric Oxide Induced Cervical Ripening in the Human: Involvement of Cyclic Guanosine Monophosphate, and Prostaglandin $\mathrm{F}_{2 \alpha}$ and Prostaglandin $\mathrm{E}_{2}$. American Journal of Obstetrics and Gynecology, 186, 745-750. http://dx.doi.org/10.1067/mob.2002.121327

[28] Ekerhovd, E., Bra, N.M., Weijdega, B. and Norstro, M.A. (2009) Nitric Oxide Synthases in the Human Cervix at Term Pregnancy and Effects of Nitric Oxide on Cervical Smooth Muscle Contractility. American Journal of Obstetrics and Gynecology, 133, 610-616.

[29] Bullarbo, M., Orrskog, M.E., Andersch, B., Granström, L., Norström, A. and Ekerhovd, E. (2007) Outpatient Vaginal Administration of the Nitric Oxide Donor Isosorbide Mononitrate for Cervical Ripening and Labour Induction Post Term: A Randomized Controlled Study. American Journal of Obstetrics and Gynecology, 196, 50.e1-50.e5.

[30] Rameez, M.F. and Goonewardene, I.M. (2007) Nitric Oxide Donor Isosorbide Mononitrate for Pre-Induction Cervical Ripening at 41 Weeks' Gestational: A Randomized Controlled Trial. The Journal of Obstetrics and Gynaecology Research, 33, 452-456. http://dx.doi.org/10.1111/j.1447-0756.2007.00573.x

[31] Eddama, O., Petrou, S., Schroeder, L., Bollapragada, S.S., Mackenzie, F., Norrie, J., et al. (2009) The Cost-Effectiveness of Outpatient (at Home) Cervical Ripening with Isosorbide Mononitrate Prior to Induction of Labour. BJOG: An 
International Journal of Obstetrics \& Gynaecology, 116, 1196-1203. http://dx.doi.org/10.1111/j.1471-0528.2009.02236.x

[32] Yazdizadeh, H., Abedi, P., Najar, S. and Angali, K.A. (2013) The Impact of Isosorbide Mononitrate on Cervical Ripening and Labor Induction in Primiparous Women with Term Pregnancy: A Double-Blind, Randomized, Controlled Trial. Iranian Journal of Nursing and Midwifery Research, 18, 246-250.

[33] Agarwal, K., Batra, A., Batra, A., Dabral, A. and Aggarwal, A. (2012) Evaluation of Isosorbide Mononitrate for Cervical Ripening Prior to Induction of Labor for Postdated Pregnancy in an Outpatient Setting. International Journal of Gynecology \& Obstetrics, 118, 205-209. http://dx.doi.org/10.1016/j.ijgo.2012.04.017

[34] Habib, S.M., Emam, S.S. and Saber, A.S. (2008) Outpatient Cervical Ripening with Nitric Oxide Donor Isosorbide Mononitrate Prior to Induction of Labor. International Journal of Gynecology \& Obstetrics, 101, 57-61. http://dx.doi.org/10.1016/j.ijgo.2007.09.027

\section{Submit or recommend next manuscript to SCIRP and we will provide best service for you:}

Accepting pre-submission inquiries through Email, Facebook, Linkedin, Twitter, etc A wide selection of journals (inclusive of 9 subjects, more than 200 journals)

Providing a 24-hour high-quality service

User-friendly online submission system

Fair and swift peer-review system

Efficient typesetting and proofreading procedure

Display of the result of downloads and visits, as well as the number of cited articles

Maximum dissemination of your research work

Submit your manuscript at: http://papersubmission.scirp.org/ 